\title{
ARAGONESE EXARICI IN THE TWELFTH CENTURY: THEIR STATUS AND CONDITIONS OF LANDHOLDING
}

\author{
Por \\ WILLIAM C. STALLS
}

In the late eleventh and twelfth centuries, as the Aragonese fitfully expanded from their hardy Pyrenean kingdom into the Upper Ebro River Basin, they subdued and subsequently ruled Muslim lands with well-developed urban and agrarian life (1). As the Aragonese conquest of these Muslim lands shaped the geographical boundaries of Aragon, so the Aragonese conquest of the lands' Muslim inhabitants affected the shaping of Christian society. The Aragonese did not cast aside the material Islamic infrastructure they had conquered; instead, they incorporated it into Christian Aragon, partly in order to exploit the resources of the newly conquered lands. Aragonese retention and adoption of Islamic irrigation practices and techniques attest to the influence of the Muslims on Christian society. Another part of the Islamic agrarian structure retained by Christians was the Muslim tenant-farmer, the ash-sharik (sharer), in Latin exaricus. In Al-Andalus, the sharik is usually defined as a tenant-farmer, leasing land from a landlord who receives a percentage of the crop (2). In its Romance or Latin form, the word sharik frequently surfaces

(1) Manuel Gómez de Valenzuela, La vida cotidiana en Aragón durante la Alta Edad Media, Colección Aragón (Zaragoza, 1980), 87. Sancho el Mayor's acquisition of Agüero in 1035 began Aragonese expansion. At least this is the view of Antonio Ubieto Arteta; see his Historia de Aragón. La formación territo. rial. (Zaragoza, 1981), 36-40.

(2) Thomas F. Glick. Islamic and Christian Spain in the Early Middle Ages (Princeton, New Jersey, 1979). 151-52: Rotert I. Burns, Muslims, Christians, and Jews in the Crusader Kingdom of Valencia: Societies in Symbiosis [New York and Cambridge, 19841, 40. Chapter one of this book, pages 39-46, summarizes and analyzes well current work on exarici. See also, Robert Burns's Islam under the Crusaders: CoIonial Survival in the Thirteenth Century Kingdom of Valencia (Princeton, New Jersey, 1973), 102-105; and Medieval Colonialism: Postcrusade Exploitation of Islamic Valencia (Princeton, New Jersey, 1975). $110-112$.

For a general bibliography on Muslims in Sharq Al-Andalus, see Míkel de Epalza, with María Jesús Paternina and Antonio Couto, Moros y moriscos en el levante peninsular (Shara Al-Andalus): introducción bibliográfica, Publicaciones del Instituto de Estudios Alicantinos, Serie 1. 86. Alicante, 1983.

Two good bibliographical surveys of Mudejars in Aragon exist: José María Lacarra, "Introducción al estudio de los mudèjares aragonees". Actas del/ simposio internacional de Mudejarismo, Teruel, 1975 (Madrid-Teruel, 1981), 17-28; Mercedes García Arenal, "Los mudéjares en el reino de Navarra y en la corona de Aragón. Estado actual de su estudion. Actas del ll/ simposio internacional de Mudejarismo, Teruel, 20-22 septiembre de 984 (Teruel, 1986), 175-186. 
in post-conquest documentation from the Ebro basin, revealing that in some form these Mudejar farmers still played an important role in the now Christian controlled Ebro River Valley. Indeed exarici are generally credited with providing the bulk of agricultural labor for the Aragonese in the Ebro River Valiey (3).

Because of the number and importance of exarici in agrarian life, scholars have scrutinized the state of exarici under Christian rule. Even in the Middle Ages exarici were being defined and categorized by both religious and legal scholars. The Fueros de Aragón equated an exaricus with a parconero (aparcero), or sharecropper (4). Ramon Marti's wordlist of Arabic and Latin used the word particeps, or joint owner, to define exaricus, meaning the exaricus could be a property owner (5). At the turn of this century, Eduardo Hinojosa, differing with these previous definitions, believed the exaricus to have the hereditary status of a serf under the lordship of Christian seigneurs (6). With the Christian subjugation of Muslims, he argues, exarici and their property had passed to the control of Christian lords. Subsequently, exarici at best retained only custodial care of their property; the lord's control of both the person and the property of exarici was paramount. Exarici were now unfree; by this view, their status changed from free tenants in the Islamic Ebro to serfs under Christian control. In varying degrees, Hinojosa's work still influences interpretations of exarici today.

More recently the Diccionario de historia de España has described the exarici of Aragon and Navarre as numerous in the Ebro River Valley, their property having passed from their control to Christian lords. Exarici had become the semi-dependent tenants of Christian lords, although juridically free and possessing freedom of movement in some cases. Again, the contention is that exarici are servile, although, in this case, this status is qualified by certain freedoms (7).

Jean-Guy Liauzu has produced the most authoritative work on Aragonese exarici in the last twenty years. Using Lacarra's valuable documentary collection for the post-conquest Upper Ebro River Valley (8), Liauzu studied the Mudejars of Aragon in the eleventh and twelfth centuries, including, natural-

(3) José María Lacarra, "La reconquista y repoblación del Valle del Ebro", in José Font Rius et alii, La reconquista española y la repoblación del país, Escuela de Estudios Medievales, 15 (Zaragoza, 1951). 70

(4) Gunnar Tilander, ed. Los Fueros de Aragón según el manuscrito 458 de la Biblioteca Nacional de Madrid (Lund, 1937), 40

(5) Eero K. Neuvonen, Los arabismos del español en al siglo Xll (Helsinki, 1941). Burns, Muslims, Christians, and Jews, 40.

16) Eduardo Hinojosa, "Mezquinos y exáricos, datos para la historia de la servidumbre en Navarra y Ara gónm, in Homenaje a Don Francisco Codera en su jubilación del profesorado. Estudios de enudición oriental. Ed. Eduardo Saavedra et alii (Zaragoza, 1904), 523-531.

(7). Pilar Loscertales, “Exáricos», Diccionario de historia de España, ed. German Bleiberg. 2nd ed. 3 vols (Madrid, 1968-69), 2:1351.

(8) José María Lacarra, "Documentos para el estudio de la reconquista y repoblación del valle del Ebro" Estudios de Edad Media de la Corona de Aragón, 2 (1946), 469-727; 3 (1947-48), 499-727; 5 (1952). 511-668. The documents used in this paper will be cited by volume and document number. 
ly, exarici because of their large numbers (9). He concluded that the status of exarici was difficult to determine from the documents. He believes that exarici could be serfs, tenant-farmers, or even free property-holders (10). But he also distinguishes between Mudejar who own property and land, and exarici who are attached to the land and are tributaries of Christian lords (11). In general, Liauzu labels as exarici serfs who farm properties for Christian landlords for life (12). These conclusions mesh with the general view of the status of exarici: basically unfree peasant farmers bound to Christian lords, their condition having changed from that found in Islamic farming practices.

This brief survey of scholarship on exarici was intented to familiarize the reader with the scholarly consensus on the status and conditions of landholding of exarici 113). The consensus holds that exarici were servile, formally bound to their Christian lords by a hereditary status, working lands over which they had no rights. This view provides a framework with which to begin to examine exarici. Upon closer examination of the primary evidence for exarici, however, this view is revealed as incomplete and faulty; it needs restructuring. In the twelfth century, exarici could be more accurately described as either tenantfarmers under Christian landlords or, in some cases, even property owners in their own right than as serfs. This description is more useful for understanding exarici in the twelfth century. To support this contention, I shall examine the status and conditions of landholding of exarici in Aragon and Navarre in the twelfth century. Since Lacarra's documentary collection is the most convenient and complete source, with and adequate number of references to exarici, I shall draw upon this very useful collection for my study.

As is the case with most terms in charters, the word exaricus is never defined concretely. Only the contest in which exarici are mentioned provides clues to their status. The mayority of documents on exarici are mundane, e.g., the alienation of property between Christians and the exarici associated with the property. Occasionally, however, exarici are caught up in more significant matters such as a power struggle between church, nobility, and king with the control of the fruits of exarici labor as just one of the prizes (14). These documents do speak clearly about one salient characteristic of the status of exarici as they came under Christian control in the twelfth century: they belong-

(9) Jean Guy Liauzu, "La condition des musulmans dans l'Aragon chrétien aux xi et xii siècles", HerpérisTamuda 5 (1968), 185-200.

(10) Ibid., 187

(11) bid., 188 .

(12) Ibid., 189

(13) José María Lacarra, a preeminent authority of medieval Aragonese scholarship, has correctly observed that the categorization of exarici as serfs misrepresents the nature of their contractual relationship with Christian lords. He notes that exarici enjoyed certain freedoms under Christians lords that preserved their rights to land tenure and that exarici of the twelfth century possessed a fluid juridical status. This paper will prove both these points. See Lacarra's uLa reconquista y repoblacion..., 71; and uintroducción al estudio...., 23.

For the view that exarici were freemen, see also. Angel González Palencia, "Notas para el régimen de riegos en la región de Veruela en los siglos XII y XIIn, Al-Andalus, 10 (1945), 83

(14) $2: 62,63(1129)$ 
ed to the royal patrimony. The earliest charters mentioning exarici concern their alienation from roval control to private authority. Document 217 offers a good example of this. In 1125. Alfonso 1, king of Aragon (d. 1134), gave various properties to his merino, Banzo Fortuñón, for various services, presumably military and personal. Part of this donation included two exarici and their properties (15). As one of the conditions of this grant. Alfonso ordered that these exarici should pass from his authority: "Let you [Banzo] have this donation exempt, free, safé and secure as your property (16)». Alfonso's donation of exarici to the monastery of Santa Cristina provides another example. Here, the monastery of Santa Cristina received them «secure, free, and exempt... from all muy descendants (17)". These documents show that in the early stages of the conquest of the Ebro, Aragonese kings controlled exarici as part of the royal patrimony and considered them a resource with which to reward faithful nobility and clergy. This pattern confirms the condition of Mudejars in general as roval men (18).

Later documents substantiate this point. In 1147, Don García of Belfort donated the soto of Mora and an exaricus residing there to the Knights Templars. Garcia stipulated that the donation should be «just as King Alfonso made the donation to me (19)». By referring to Alfonso's donation, Garcia reaffirmed his legal rights to the property and the exaricus in order to alienate them. This document was drawn up at Tudela in 1147. Since Tudela surrendered to Alfonso in 1119 and Alfonso died in 1134. Alfonso originally donated this property to Garcia sometime between these two dates. Again this evidence indicates that exarici originally comprised part of the royal patrimony in the immediate stages after Alfonso's conquests. Only later did exarici pass from royal to private control. By such donations, Alfonso was obviously trying to attract Christian settlers to a still heavily Muslim land.

Document 255 presents explicity how the status of exarici could change after their alineation from royal control. Andrés and his wife, Mayor, have given some property in Murel along with an exaricus and his family to the church of Santa María of Tudela. The document notes that this property and the exaricus came from Sancho VI, king of Navarre (1150-94). Furthermore, the document stresses that Santa María will have the exarici "just as the king gave them free [horros] from every obligation of sofra [labor service], of iuueria [tax on draft animals], of quarto [one fourth of agricultural produce], of sadaqat [livestock renders] (20) $)$. Not only this, the exarici are exempt from the royal jurisdiction of the local castellan: «Let them not respond to any alcaide of the

\footnotetext{
(15) 3:127 (1125, September 29): "Dono tibi in Gallur illo axaric". "Dono... tibi in Pinsec illo xaricon.

(16) Ibid.: :Abeas eum ingenuum et liberum et francum uel securum ad tuam propriam hereditatem".

(17) 5:320 (1127, March): "Francos et liberas et ingenuas, salva mea fidelitatem et de omni mea posteritate».

(18) I did not find a document from either the decade of the 1120 s or the 1130 s where exarici seemed to be directly under control without having passed first from royal control.

(19) 5:362 (1147, Aprill: «Sicut mihi fecit donatiuum rex Adefonsus».

(20) 3:255 (Post 1151): «Sicut rex eos mihi dedit horros de omni servicio de açofra, de iuuveria, de quarto, de açadecan.
} 
castle (21)". Furthermore, the property belonging to the exarici before Andres' acquisition was considered part of the royal patrimony: "De illa quam de patrimonio [exarici] habebant, siue de regalin. The holdings of the exarici, probably by right of conquest, were part of the royal patrimony as was befitting the property of the king's own men.

This document is unclear about the obligations owed the new lords, though logically there would be some. However, it does record how exarici could be obligated to royal authority -in this case, by labor services, perhaps discretionary or fixed by custom; by crop and livestock renders; and, by the jurisdiction and protection of royal justice in the form of the alcaide (22). Even more, the Romance transliterations of the Arabic words for these labor services and livestock renders - sofra from al-sukhra, and açadeca from sadaqatlink the Islamic Ebro with the Christian Ebro. Al-sukhra is the Arabic equivalent for the kind of work obligated by the sofra, and șadaqat is a levy in Islamic law on types of livestock (23). The Islamic system of obligations and services intersected with the needs and interests of victorious Christians. Rather than destroy an established system of renders, Christian king like Alfonso I retained it as a means of exploiting Mudejars, including exarici. Although related to agriculture and obligations on rural Mudejars, including exarici. Although related to agriculture and obligations on rural Mudejars, these obligations and renders were probably general ones owed by Muslims to Christian lords, and not specific duties that spoke of a lord-serf relationship or made exarici serfs. At any rate, this document explains what happened in the twelfth century when exarici passed from royal to private authority-obligations and legal relationship binding Muslims as royal men were severed.

This document leads to other important questions on the status and conditions of landholding experienced by exarici. How did exarici hold property? Were exarici landholders free or servile property holders? The answers to these questions would resolve the puzzle of both their juridical status and conditions of landholding. Other questions also need asking: What were the exact requirements of their tenancy? How much of their produce was owed to Christian seigneurs? The answers to these questions seem recondite as one combs carefully through often frustratingly vague documents. For example, Alfonso I gives an exaricus, described by name and residence, to Faulorichero for various services. Faulorichero should have uthat man secure and free and ex-

(21) lbid.: "Non respondeat ad ullo alcaid de illo castellon.

(22) Perhaps this document could be interpreted to mean that roval exarici were generally exempt from these renders and services. If these royal renders and services had not been incumbent on these exarici of the king, then there would have been no need to mention them. Thus, they are mentioned

(23) Robert I. Burns, "Socioeconomic structure and continuity: Medieval Spanish Islam in the tax records of Crusader Valencian, in The Islamic Middle East 70-1900. Studies in Economic and Social History (Princeton, New Jersey, 1981), 254, 264-65. In the revision and Catalan translation of Medieval Colonialism, forthcoming from Tres i Quatre press in Valencia, Robert Burns elaborates, corrects, and advances his ideas on the sofra. On the sofra as labor service, see also, Mikel de Epalza and Maria Jesús Rubiera, "Un servicio obligatorio islámico en Al-Andalus: la sofra (sujra), Sharq Al-Andalus 3 (1986). $33-37$ 
empt, for giving and for selling and doing with according to your own willy (24). This phrase suggests that the transferring of lordship over an exaricus serf or even slave has just taken place. Also, in another document, a certain Lozaro, in his will, bequeathes two exarici, and the recipients apparently will exercise a plenary lordship over the person of these exarici: "And about the above writing concerning these exarici, let them, Pelayo my squire and my "amma" [Urraca], do with the exarici as they please, and after their deaths [Pelayo's and Urraca's] let the exarici remain with their descendants [Pelayo's and Urraca's] forever" (25). These exarici seem to be serfs, if not slaves.

If only this type of limited evidence existed for exarici, them one could prudently conclude, as scholars have done, that all exarici were serfs in the twelfth century. Fortunately, the documentation for the twelfth century has been generous and left more revealing evidence on exarici. In fact, the documents suggesting that exarici were servile do not typify the evidence as a whole. What the more informative documents in Lacarra's collection do reveal will now be analyzed in order to draw some general conclusions about the status of exarici as a whole in the twelfth century (26).

Several documents address the question of how exarici held their land. When certain rights over exarici were being transferred from the Christian lord to another - whether royal, noble, or ecclesiastical - the holdings associated with the exarici were often mentioned. The coupling of exarici and their holdings indicates that they go hand in hand. Furthermore, a formulaic phrase denoting property rights often describes the link between exarici and their holdings. This phrase is found in Alfonso's donation of an exaricus and his holdings to Fortuñon Iñiguez. The document records that this exaricus, Ab Ayub by name, "with his houses and this property" now belongs to the personal holdings of Fortuñon (27). The document qualifies how Ab Ayub holds his property: "With his houses and property just as he was the possessor [tenente] on the day this charter was made" (28). The key phrase here is «just as he was the possessor (sicut erat tenente), for it is a formulaic phrase in this type of charter Latin signifying ownership or possession of property involved in a transaction (29). In other words, at least until the time of the donation and probably even after it, Ab Ayub was the tenant on this land, having rights of possession, the property encumbered with him. Alfonso has transfer-

(24) 5:333 (1134, February): “Habeas illum francum et liberum et ingenuum per dare et vendere et facere inde totam tuam propriam uolantatems.

(25) 5:398 (No date): «Et de hoc supra scripto, Pelaio meo escutero et mea amma, faciant suam propriam uolantatem et post mortem suam, remaneat ad suam posteritatem per secula cunctan.

(26) I thank Robert Burns of the University of California, Los Angeles, and Dr. Lynn Nelson of the University of Kansas whose timely criticisms improved the following section of this paper. Of course, all errors are mine.

(27) 3:174 (1133, September): «Dono... uno exaric, nomine Ab Aiéb, cum suas chasas et sua hereditate... ad uestram propriam uolantatemn.

(28) Ibid.: "Cum suas chasas et sua hereditate, sicut erat tenente illo die quando ista carta fuit facto".

(29) Otiverio Nortes Valls, "Estudio del léxico medieval en diplomas aragoneses anteriores a 1157 , Archivo filologia aragonesa 24-25 (1978), 61-62 
over property and tenants, and not rights over a serf and his holdings (30). This exaricus is no serf; he is most likely a tenant farmer, working these lands for Fortuñón.

This document is not isolated, speciously plucked out of context, for exarici were often considered tenentes. In 1124, Alfonso I gave to Guillermo Sánchez of Tena lands, vineyards and houses, "as much as belongs to that property where the tenentes were my Moorish exariciy (31). Again, exarici are described as holders of property. Also, in a previously cited document, Alfonso ! gives away more of this patrimony, this time to his merino, Banzo Fortuñón. Two exarici, one in Gallur and the other in Pinseque, are included and called tenentes. The exact holdings of the exarici are not spelled out; only «as much as pertains to him [the exarici]» is specified (32). However, Alfonso makes Banzo the tenente of all this property, including presumably that of the exarici: "You then were the tenente on the day this charter was made" (33). Banzo, as tenente, is invested with the ownership of these properties. Alfonso does not indicate how Banzo's ownership affects the status of the exarici as tenentes; perhaps it has (34). Nevertheless, exarici have been described as tenentes, showing that they possessed property rights over their holdings. Also, as Muslims, exarici were under the authority of the crown, the power of which superseded the rights of Muslims. Consequently, Alfonso's right to diminish the property rights of Muslims, as may have happened in this case, does not detract from the rights of Muslim exarici to own or hold property freely. Also, this charter has not made exarici servile, for this transaction concerns property rights, not the disenfranchisement of the liberty of exarici.

The context of other documents even where exarici are not called tenentes suggests that they were tenant farmers and provides insights into the conditions of their tenancy. In document 164, Alfonso I has granted some exarici to his scribe, Juan Pérez. As one condition of the grant, Juan could receive only one-fifth of the property of the exarici, meaning one fifth of the property's yield, during the lifetime of the exarici. After their deaths, all the property should be Juan's: "You should have one-fifth from that property in their lifetime, and after their deaths, you should have all of the property" (35). The exarici red plenary lordship over the property to Fortuñón (habeatis illum salum et liberum et ingenuum et francum uos et filii uestril, but Ab Ayub, as tenente, seems to have retained rights of property and residence. He now only has a different landlord. In this document, Alfonso has only transferred certain rights

(30) Burns, Islam under the Crusaders, 103, n. 39

(31) $3: 120$ (1124, April): "Quantum id illa hereditate aper tinet unde fuerint tenentes illos meos exaricos mo$\operatorname{ros} n$.

(32) 3:127 (1125, September 29): "Quantum ad illum ibi pertinet"

(33) Ibid.: "Ego mandaui tibi illud et tu eras inde tenente die quando ista carta fuit facta».

(34) This is also the case in documents 264 and 266. Lady María received an exaricus described as a tenente with his property from Sancho VI. In document 266. Lady Maria gave this exaricus and his property to the church of Santa María of Tudela. She also gave all the property in the district where the exaricus lived to Santa Marfa of Tudela and noted that Sancho had made her and her dead husband the tenentes of this property, meaning presumibly that of the exaricus' as well.

(35) 3:164 (1131, May 18): «In tota uita de ellos habeas illo quinto de hereditate illius et post morem eius habeas tota illa hereditate». 
seem to have some type of control over the property that Juan cannot override - he can only receive one-fifth of the land's production as rent. This condition indicates that the exarici held the property under a lifetime lease that called for one-fifth of the land's production as rent. These exarici were not serfs; they had property rights that even Juan's ownership could not supersede. The conditions of the new lease under Juan were probably the same as the old one held by Alfonso; he just transferred the ownership of the lease to the exarici's new landlord, Juan.

Other documents also indicate that exarici held their lands not as serfs but with some type of free tenure. In document 395, Lop Aznárez sold his holdings in Valtierra to Muça for fifteen hundred morabetinos. In the list of agricultural properties being sold, an exaricus and his family is recorded: "Waters, reed beds, an exaricus by the name Abdela Aven Alcáld and Áchi his wife with all their properties and all my rights that belong to me in Valtierra» (36). Significantly, the property of the exaricus is noted, thus distinguishing it from Lop's. If the exaricus were merely a serf, without property rights, then why did Lop need to distinguish the property of the exaricus from the other property already listed? Presumably, the property was encumbered with Abdela by some type of contract. Since the property being sold is agricultural, Abdela was probably a tenant-farmer, working land for his Christian landlord, Lop Aznárez. Lop was only selling his rights of landlordship over the holdings of his exaricus tenant.

In the twelfth century, Christians regularly contracted exarici as tenantfarmers as three documents on disputes about tithes on agricultural production of land worked by exarici for Christians show. Two of the documents detail Alfonsol's orders to his justiciars in Zaragoza and Tudela to enforce his decision that land farmed by exarici, but held by Christians, should pay tithes and firstfruits. The land the exarici now worked had also previously been worked by exarici who had abandoned it and emigrated to Al-Andalus (xaricos moros. . itos uel andatos ad terras de moros) (37). After the departure of the exarici, Christians had seized these lands and then let them out again to other exarici for half of the land's yield (38). The clerics of Tudela and Zaragoza claimed that not only the half of the land's yield given over to Christian landlords should be tithed but also the half kept by exarici as well (39). Alfonso decided the cleric's plea in their favor, resolving that all of the land was subject to ecclesiastical taxation.

Alfonso 11, count-king of the crown of Aragon (d. 1196), faced a similarly thorny problem forty-four years later. In this case, Christians had given their

(36) 5:395 (1 188, January): «Aquas, cannares, axaricos per nomen Abdela Aven Alcálơ et Achi uxorem eius, cum omnibus suis hereditatibus et cum totis meis directis".

(37) $2: 62$ (1129, October 10$)$.

(38) Ibid.: afllos christianos... prendunt illas hereditates de lures xaricos moros... et donant illas hereditates pro laborare ad alios moros ad medietatem".

(39) 2:63 (1129, October 10): "De lure medietate donant decimam illos christianos et de illa medietate de illo moro non donant ulla decimam ad Deum*. 
lands to exarici and then claimed this land's exemption from the tithe and firstfruits because Muslims worked it. "They gave their properties and their honores for farming and working to their Saracen exarici, [but] neither did they give the tithe nor the firstfruits from this part of the property or honore that the Saracen exarici were working and farming" (40). Also, these lands had been subject to the tithe before being given to exarici (40). Also, these lands had been subject to the tithe before being given to exarici (41). Alfonso, recognizing the precedent established by his great-uncle. Alfonso I, ruled that this land's yield could not evade the financial jurisdiction of the church. In these three documents, a revealing power struggle between nobility, church, and king has ocurred - a struggle that suggests the church and royal authority were losing since the same problem confronting roval and ecclesiastical authority crops up continually in the twelfth century.

Besides describing this power struggle, these three documents point out well the pattern and conditions of exarici landholding in the twelfth century. After the exarici had emigrated to Al-Andalus, Christians had taken over these lands for the purpose of giving them to other exarici for working. Documents 62 and 63 record that Christian landlords gave (donant) these lands to exarici in return for one-half of the land's yield. Since these lands are given -perhaps the better word is leased - to exarici. Christian landlords were settling tenantfarmers on these lands, and not serfs. These exarici were tenant-farmers working under a lease of unspecified duration that called for one-half of the land's yield to be paid as rent. Exarici were clearly leasing land, not entering into servile status to work the land.

This same condition of landholding also existed in document 269, where Christians lords, called magnates, knights, and burghers (42), gave (traderentur, dabant) land to exarici to farm for an unspecified length of time and rent, which was to be paid from the land's yield. Again, this document confirms that exarici were tenant-farmers, returning a percentage of their crop to Christian landlords.

These exarici tenant-farmers of documents 62,63 and 269 apparently possessed a juridically free status - they freely contracted with Christians landlords and had freedom of movement. The new exarici tenants took up residence on land that was abandoned; this implies their movement from somewhere else to work this land. In order to move into this land, they had to contract leases with Christian landlors, as has been shown above. If these exarici had a servile status that bound them to lord and land, then these rights to engage in contracts and change residence would have been restricted. The

\footnotetext{
(40) 3:269 (1169, Jume 16): "Dabant hereditates suas et honores ad excolendum et laborandum suis exarigs sarracenis, nec dabant decimam nec primiciam de illa parte hereditatum uel honorum, quam sui exarigs sarraceni laboraban et excolebanta.

(41) Ibid.: "De illis uero hereditatibus uel honoribus que fuerunt quondam sarracenorum et postea in manu christianorum deuenerunt uel deuenerint unde semel Ecclesia decimam accepit».

(42) 3:269: "Potestates et aliis milites neconon burgenses".
} 
documents record no Christian objections to these rights of exarici, indicating their acknowledgement by the Christian lords of the Upper Ebro, whether church, king, or nobility. Exarici were not formally bound to their Christian lords by a hereditary status. These exarici tenant-farmers had a juridically free status as their rights of movement and to ente into contracts show (43).

The status of exarici was not always hereditary or lifelong as document 267 indicates. In this case, two Muslims, along with two Christians, alienate lands to the clerics of Santa Maria of Tudela for a sum of money. The charter also records that these two Muslims had been the exarici of the father of one of the Christians $(44\}$. Unfortunately, the document omits how the relationship between the former exarici and the Christian was severed. Perhaps, if exarici were truly serfs, then one could argue that the Christian lord of the exarici had only manumitted the exarici. Since most evidence contradicts the view that exarici were serfs, this interpretation is least plausible. More likely, these exarici had probably left their contract with the Christian and were now landholders in their own right, as their alienation of property to the clergy of Santa María shows. At any rate, this document does suggest that the status of exarici was not always hereditary or lifelong.

The description of the exarici in the three documents on disputes over tithes probably applies to the exarici of the Upper Ebro as a whole. Alfonso I's decision covered both Tudela and its sorrounding areas and Zaragoza (presumably the diocese) in the first half of the twelfth century, and Alfonso II's applied to the bishopric of Zaragoza in the second half of the twelfth century (45). Thus, these documents describe the exarici of these areas. If so, then this description of exarici can be assumed to be the norm for exarici in the areas of Tudela and Zaragoza, which represent a substancial portion of the Aragonese and Navarrese Ebro River Basin. Consequently, the exarici in these documents probably represent the exarici as a whole in the Upper Ebro. And, as we have seen, exarici in these documents were tenant-farmers with a juridically free status. This description of the status and landholding conditions of exarici would best then describe exarici as a whole in the Upper Ebro in the twelfth century.

The Christian lords of the Aragonese and Navarrese Ebro probably granted such favorable terms of landholding and personal status to exarici for several reasons. After the conquest of these Muslim lands, Christian lords like Alfon-

(43) Alfonso lopposed, however, their migration to Andalusia, Valencia in this case, because Muslims constituted a key financial resource of the crown. He orders that "you [his justiciar] should not let any Moor go to the lands of Valencia, and those who have gone without my permission. I command that you sieze all of their goods». (2:63) This movement must have been large and usually unimpeded since Alfonso has to order his justiciar to stop it.

(44) $3: 267$ (11:61, April 1): «Mahomet Abnalfarra et soror mea Axa, qui fuimus exaricos de Raimundo Berenguer, patre de dompna Christian, uendidimus duas nostras peças clericis Sancte Marie... per ViH morabetinos lopisn

(45) 2:62: «Populatores de Tudela et de illas alias uillas"; 2:63: «Adefonsus Dei gratia imperator, uobis Quadrat iusticia de Saragoza»; 3:269: «Ecclesie Sancti Saluatoris Cesarauguste et episcopo et clericiis et omnibus successoribus suis eiusdem Ecclesien. 
so I struggled with the problem of Christian settlement of predominantly Muslim lands (46). They lacked a strong Christian population with which to exploit the rewards of their conquest, the fertile lands of the Ebro. In a land seriously underpopulated with Christians, Mudejars, including exarici, formed an irreplaceable labor force by flight to Al-Andalus (47), exarici were allowed to lease and work land freely by contract with Christian lords. This arrangement would have benefitted both sides: exarici who would develop and work freely lands under the security of a contract, while Christian lords could rely upon contractual obligations with exarici to farm these lands. Finally, a massive disenfranchisement of exarici liberty would have forced their flight en masse from Aragon, resulting in the disruption of a well-developed Islamic agrarian structure. In turn, this disruption would have damaged the ability of Christian lords to profit from their holdings. The Christians of the Ebro needed and prized the sweat of exarici labor to exploit these lands. The worth of the exarici is reflected in this Aragonese saying: "Quien no tiene Moro, no tiene oro".

As the previous evidence has demonstrated, exarici would best be categorized as tenant-farmers, and not serfs. About this conclusion, there can be no argument. Some of the evidence raises another question about the conditions of landholding enjoyed by exarici in the twelfth century. Could the term exarici have been used in documents to describe freeholding Mudejar farmers and property owners as well?

Document 255, previously mentioned, provides some of the strongest evidence that Mudejars labelled exarici could own property. The church of Santa María of Tudela received some exarici from Andrés and his wife, who had the exarici given to them by Sancho VI. The exarici were tenentes of the property when Sancho made the donation, and they still were the tenentes of this property after the donation. Since Sancho's donation of the exarici to Andres, they have added to this property of which they are tenentes:

I give these foresaid exarici to the foresaid church with all the property where they were tenentes on that day in which Sancho made the donation to me, namely of that which they have from their patrimony, either from the royal patrimony, or from whatever they are tenentes or were able to acquire beforehand (48).

\footnotetext{
(46) Lacarra, "La reconquista y repoblación...., 74-75. Also, I think Dr. Lynn Nelson of the University of Kansas whose ideas on this question were most helpful.

(47) According to documents 62 and 63, this flight to Al-Andalus was ocurring anyway. Since Christians took over these lands after the exasici had felt, perhaps Christians had pressured exarici to leave in order to acquire the their property.

(48) 3:255 (Post 1151): "Dono istos supradictos exaricos supradicte ecclesie cum tota hereditate unde erant tenentes illo die quo rex Sancius donationem fecit mihi de ea, scilicet de illa quam de patrimonio habebant, siue regali uel undecumque sunt tenentes uel in antea adquiere poterints.
} 
The property held as tenentes is also specified: "Houses, vineyards, gardens, fields, woods, cleared, uncultivated and planted» (49).

These exarici, called tenentes, were freeholding property owners, as their ability to acquire and hold property at their own discretion shows. At least in the case of these exarici, tenentes probably describes owners of property. Since the exarici and property were subject to and the property of a Christian lord, one could argue that the Christian lord was the true proprietor of this land. Although not defined in this document, this Christian lordship undoubtedly limited in some sense exarici property rights. But this lordship did not destroy exarici property rights, for they could acquire and hold property freely. And the exercise of such rights is equivalent to ownership. Andrés has not granted serfs to the clergy of Santa Maria but rights of lordship over property first granted to him by Sancho VI. These exarici seem to have been both property owners, acquiring and holding land freely, but, at the same time, still subject to Christian lordship (50). Also, the list of agricultural properties the exarici might hold was substantial, suggesting that the exarici were prosperous landowners.

The documents on the dispute over the payment of tithes from lands worked by exarici that Alfonso I settled also indicate exarici ownership of land. Document 62 suggests the exarici around Tudela who had emigrated to Al-Andalus had abandoned their own lands. After they left, "the Christians who live at Tudela and other villages seized the property of their Moorish exarici who went to the land of the Moors and they gave these properties to other Moors for half [of the land's yield]" (51). The seizure does not suggest prior Christian ownership of these lands; only after the departure of the exarici did Christians take over these properties. By their seizure of these lands, Christians had evidently assumed their ownership because they could place exarici as tenantfarmers of these lands. The old exarici owners of these lands had gone, thus opening them up to Christian acquisition and exercising of subsequent proprietary rights, i.e., the leasing of these lands to other exarici.

These exarici - as Mudejars - had a legal right to own these lands. Despite the expulsion of Muslims from within the city walls of Tudela a year after the city's conquest, the surrender constitution of Tudela preserved Muslim ownership of property outside the walls, including the right to sell and dispose of property freely (52). The lands exarici worked outside the walls of Tudela could be their own. Thus, exarici ownership of land is consistent with the legal privileges afforded them under Christian rule.

(49) Ibid.: "Casas, lineas, ortos, peças, sotos, eras, siue hermum siue plantatum».

(50) Robert I. Burns, "Muslims in the thirteenth-century reaims of Aragon: Interaction and reaction", in The Latin West and the Muslim Frontier: Medieval Societies in Comparative Perspective, ed. James Poweli (Princeton University Press forthcoming).

(51) 2:62: "Illos christianos qui sunt populatores de Tutela et de illas alias uillas prendunt illas hereditates de lures xaricos moros et donant illas hereditates pro laborare ad alios moros ad medietatemn.

(52) Alfonso l's agreement with the Muslims of Tudela is found in Colección de fueros municipales $v$ cartas pueblas de los reinos de Castilla, León, corona de Aragón y Navarra coordinada y anotada, ed. Tomás Muñoz y Romero, vol. 1 (Madrid, 1847; reprint ed. Madrid, 1970): 416-417. 
An even stronger argument exists for exarici ownership of these lands. The document records no ecclesiastical claim on the produce from the land worked by the original exarici inhabitants. The church probably did not demand the tithe and firstfruits from the land because the exarici owned this land, and Muslim property, at least according to the letter of the law, was not subject to ecclesiastical taxation (53). Therefore, the church enjoyed no right to touch the fruits of the original exarici tenant's labor. Only after the Christians had assumed the ownership of these lands abandoned by exarici could the chlurch demand their fiscal dues from these lands. In an apparent acknowledgment of exarici proprietorship of these lands, the church had not contended for the tithe and firstfruits from these lands before their seizure by Christians. This acknowledgment debunks the idea that exarici were only serfs and also provides solid evidence for suggesting that exarici were land owners. This exarici proprietorship of land could have been one pattern of exarici landholding in the regions of the Upper Ebro, where in the twelfth century, exarici lived as freeholding proprietors of farms.

If exarici were truly proprietors of property, then instances of exarici alienation of land should be found. Such an instance was recorded in document 355. Here, Giraldo Ainet sells to Don Navarro his share of a mill purchased from a Christian and an exarici: "We bought that mill from Peter... and from his exaricus the son of Zuleman" (54). Although the exaricus is called Peter's exaricus, the two seem to be more like business partners in a substantial capital investment, a mill, than anything else. At any rate, by this purchase, Giraldo has acknowledged this exaricus's ownership of property

After the discussion of the status and conditions of landholding enjoyed by exarici, one final observation should be made about the evidence on exarici from Lacarra's valuable collection of documents. The term exaricus is usually associated with Mudejars who were under Christian lords. Evidence exists, however, suggesting that this was not always the case. Document 257 speaks of a field next to the field of "Gualit exarico de Abbofaçam». Gualit is identified by his status as an exaricus of Abbofaçam. Apparently Gualit works this field for Abbofaçam, his landlord. Also, these two men have Arabic names, proving that this exaricus-landlord relationship was between two Muslims. Document 134 records a similar case. Two Christians have bought property from a Muslim woman, who, interestingly, was described as "the mother of Bolageg abin Frauchat her exaricus" (55). This woman's son is called her exaricus. Presumably, this exaricus son farmed and worked his mother's property; therefore, the designation of exaricus. In fact, Christians were even sometimes called exarici in the twelfth century; and this well before the term was more commonly applied to Christians in the fourteenth century (56). Thus

(53) Burns, Medieval Colonisalism, 190

(54) 5:355 (1145, January): "Nos comparauimus illo mollino de Petro... et de suo eskarig filio de Zuleman”. (55) 3:134 (1127, March): "Hec hereditate de Caida mater de Bolageg abin Frauchat suo axaric".

(56) $2: 62(1129$, October 10): "Habuerint baxatas illas hereditates ad lure xaricos christianos». Also, Jews are mentioned as working lands for Christians: «llos iudeos qui laboraverint illas hereditates de illos christianos». On Christians called exarici, see Francisco Macho y Ortega, "Condición social de los mudéjares 
the word exaricus can apply to all peasant farmers of the Upper Ebro in the twelfth century. This term was used more fluidly in the documentation of the twelfth century than scholars have previously allowed.

To be sure, exarici in the twelfth century could be serfs or, sometimes, even something resembling slaves; but just as surely, this was not usually the case (57). They were tenant farmers, leasing and working land freely, and turning over to their landlords one-fifth to one-half of the land's yield as rent (58). Some exarici were also probably landowners in their own right as well. The presence of exarici was strong in the Christian kingdoms of the Upper Ebro, probably even a majority of peasant farmers in certain areas (59). This numerical strength of exarici was odd, however, for the actual status of exarici was that of a minority, their strength of numbers left ineffectual by the preeminence of Christian power and authority. Despite their ubiquity, exarici were the real minority of the rural geography of the Upper Ebro they inhabitated, enmeshed in the equally ubiquitous power of Christian lords. Perhaps a charter of Ramiro Il, king of Aragon (1134-1137), will clarify this point. Ramiro gave to Gaiget of Longares chalf from my fields and from all my agricultural holdings... and that exaricus I have there [in Julisbol] by the name of Muhammed Abengomur with his uncultivated and cultivated fields» (60). Muhammed clearly had holdings of his own, yet they were only properties contained and submerged within the larger holdings of his Christian lord, Ramiro II. This document suggests how the holdings and proprietary rights of exarici - which exarici undeniably possessed - were enjoyed. Although recognized as independent, the proprietry rights of exarici functioned within the context of superior Christian authority. Whether freeholding or not, exarici and their holdings and consequently their lives - were caught up in the larger structure of the landholdings of the Christian masters of the Upper Ebro.

aragoneses (siglo XVM". Memorias de la Facultad de filosofía y letras de la Universidad de Zaragoza. ( (1922-1923), 150.

(57) See documents 333 and 398 above on exarici as serfs.

(58) The percentage of the crops owed to Christian landtords varied. In some cases it could be one-fifth (document 164), in others one-half (documents 62 and 63), and perhaps even one-fourth (document 255 ) In the last case this may be a general render owed by Muslims rather than a percentage of the crop fixed by a lease between landlord and tenant

(59) Mudejars were heavily concentrated atong the course of the Ebro, especially around Tudela and Zaragoza, and also along the course of the Jalon. The mayority of these Mudejars, who were inhabitating some of the best agricultural lands in Aragon. were farmers. When de Moriscos were expelled from Aragon in 1610 , they still accounted for $15.2 \%$ of the total population of Aragon. The Morisco expulsion devastated the population of some villages, where Moriscos were in the majority. For example, Ricla, which is located on the Jalón River, saw its population drop from 250 to 40 . If the Morisco population was still this strong in the early seventeenth century, then it was certainly as strong or stronger in the twelfth century. See Lacarra, "La reconquista y repoblación...., 68; "Exputsión de los Moriscos", Gran enciclopedia aragonesa, 13 vols. (Zaragoza, 1980-1983), 9:2376. For Ricla's drop in population, see Henri Lapeyre, Géographie de l'Espagne morisque (Par's, 1959), 106.

(60) 2:83 (1134, octobeer 2): «llla medietate de mea laborança et de totos meos alhobzes... Et illo axarico quod ego ibi habeo per nomen Mahomet Abengomur cum ermum et populatum. 